\title{
Securitizing the past: a discussion on the connections between heritage and security ${ }^{1}$
} Mattias LEGNÉR

\begin{abstract}
Are there connections between security policies, peacebuilding, and heritage politics? The first aim of this paper is to discuss how heritage policies sometimes are used to add to and reinforce security policies and practices. This issue is largely unknown and remains to be researched. Secondly, it would also be of importance to try to better understand how security policies may be influenced by notions of heritage and certain interventions on heritage sites. It is argued that it has become necessary to move beyond the study of wars to better understand how heritage affects security and vice versa not only in conflicts but also in peacetime and in "afterwar" periods. The paper builds on a critical reading of previous research mainly on heritage studies and partly on security studies, and on a case study of Swedish-led heritage interventions in the Balkans following the Yugoslavian wars. The case study discusses how issues of security and safety may become relevant in heritage politics in the Balkans following the Yugoslavian wars. It serves to demonstrate how heritage interventions can be seen as either providing security in a community or constituting a threat to its survival.
\end{abstract}

Keywords: Securitization, cultural heritage, reconciliation, post-war reconstruction, the Balkans, Insecurity, conservation, Urbicide

\section{Introduction}

This paper explores the possibilities of excavating the connectedness between heritage politics, security, and peacebuilding. Heritage is sometimes understood as an inheritance of traditions, objects, buildings, and sites. It can also be understood as ways of governing and managing the past for contemporary and future needs. It is this latter understanding of the heritage concept that is applied here. The aim is to identify and discuss the potential of a new and until now completely overlooked field of research.

Are there connections between security policies, peacebuilding, and heritage politics? Much of studies on the politics of heritage have so far focused on dissonance, conflict, and contestation in governance, and the dialectic between preservation and destruction. ${ }^{2}$ The first aim of this paper is to discuss how

1 A draft of this paper was presented orally at Svenska historikermötet $i$ Sundsvall (Conference of Swedish historians, Sundsvall, 10-12 May 2017).

2 The list of literature that could be cited is long. Some of the most important contributions in recent years are: J. E. Tunbridge \& G. J. Ashworth, Dissonant heritage: the management of the 
heritage policies used to add to and reinforce security policies and practices may be. Secondly, it would also be of importance to better understand how security policies may be influenced by notions of heritage and certain interventions on heritage sites. It is necessary to move beyond the study of wars to better understand how heritage affects security and vice versa not only in conflicts but also in peacetime and in "afterwar" 3 periods.

The paper builds on a critical reading of previous research mainly on heritage studies and partly on security studies, and on a case study of Swedish heritage interventions in the Balkans following the Yugoslavian wars. A first purpose of the case is to ground the general argument that heritage interventions sometimes may be connected with issues of security and the building of peace. A second purpose is to show which expressions these connections may take and how they are perceived by those involved in the interventions. A third purpose is to ground this discussion in actual fieldwork experience, rather than "just" in previous research or policy discourse.

\section{Heritage, international relations, and security}

Heritage studies, art history, and cultural property law have to some extent studied how works of art, monuments, and museums have been entangled in conflicts and international relations. ${ }^{4}$ These studies have however not made use of the methodological and theoretical contributions made by security studies, international relations or peace studies in recent years.

There are numerous ways in which security issues of different kinds may become relevant in heritage governance. Some of them are obvious and have been the object of research for some years, whereas others are not as apparent. In order to make an analysis of previous contributions to the understanding of the connections between security and heritage, research has been divided into two

past as a resource in conflict (New Jersey: Wiley, 1996); H. Silverman (ed.), Contested Cultural Heritage: Religion, Nationalism, Erasure, and Exclusion in a Global World (New York: Springer, 2011); R. Layton, P. G. Stone, J. Thomas (eds.), Destruction and Conservation of Cultural Property (London: Routledge, 2001); M. Coward, Urbicide. The politics of urban destruction (London: Routledge, 2009); R. Bevan, The Destruction of Memory. Architecture at War (London: Reaktion Books, 2006); D. Gamboni, The Destruction of Art. Iconoclasm and Vandalism since the French Revolution (London: Reaktion Books, 1998).

3 The term "afterwar" is used by A. Herscher, Violence Taking Place. The Architecture of the Kosovo Conflict (Stanford: Stanford University Press, 2010), 124.

4 For example: M. L. S. Sørensen \& D. Viejo-Rose (eds.), War and Cultural Heritage (Cambridge: Cambridge University Press, 2015); M. M. Miles, Art as Plunder. The Ancient Origins of Debate about Cultural Property (Cambridge: Cambridge University Press, 2008); L. H. Nicholas, The Rape of Europa: The Fate of Europe's Treasures in the Third Reich and the Second World War (New York: Vintage Books, 2009). 
categories here: heritage in security, and heritage as security. The most important reason for carrying out this dichotomisation is not to give the impression that the world can be neatly arranged into boxes with clearly defined contents, but rather to show that contributions have mostly been made to the first of the categories, leaving the second to a great deal unexplored. As Lene Hansen has put it, for "problems or facts to become questions of security, they need (...) to be successfully constructed as such within political discourse." 5 This should be equally true for the relationship between heritage intervention and security.

Heritage in security is about how heritage becomes an object of interest in conflicts for different actors. These actors could be warring parties but could also be traders, diplomats, and politicians, scholars, relief workers, the population in conflict areas, refugees, etcetera. One area of quite a bit of research here has obviously been how to protect and secure monuments and artworks in war-time, and the successes and failures in doing so. ${ }^{6} \mathrm{~A}$ few examples can be mentioned here, such as the work of the Allied forces during the latter part of World War II to identify, protect and return stolen art, the failure to protect museums and archaeological findings following the Iraq invasion of 2003, and the looting of museums and burning of historically valuable buildings during the Arab Spring. Another area that is currently the subject of much research is the illegal trade in antiquities, how to map it and understand it in order for the international community and individual states to be able to counter it. ${ }^{7}$ The chaos of the ongoing conflict in Syria and Iraq is proof to the difficulties but also possibilities of combatting illegal trade. Militarisation of urban space and how it affects collective memory, history writing and heritage is a third area that has attracted quite some interest from scholars working in a range of different disciplines. ${ }^{8}$

Heritage as security, on the other hand, is a category in which heritage leaves its passive role as an object of violence, crime or other action in a conflict. Instead, it becomes viewed, discussed and treated as an agent capable of contributing

5 L. Hansen, Security as Practice. Discourse Analysis and the Bosnian War (London: Routledge, 2006), 33-34.

6 For example: L. Rothfield (ed.), Antiquities under Siege: Cultural Heritage Protection after the Iraq War (Lanham: AltaMira Press, 2008). P. G. Stone, J. Farchakh, R. Fisk (eds.), The Destruction of Cultural Heritage in Iraq (Woodbridge: Boydell Press, 2008); J. Kila \& J. Zeidler (eds.), Cultural heritage in the cross-hairs: Protecting cultural property during conflict (Leiden: Brill, 2013).

7 A survey of recent research is presented in M. Legnér, 'Attacker mot kulturarv i väpnade konflikter: En forskningsöversikt', Militärhistorisk tidskrift 2016, 150-153.

8 For example: S. Graham, Cities Under Siege. The New Military Urbanism (London/new York: Verso, 2010); M. Coward, 'Network-Centric Violence, Critical Infrastructure and the Urbanization of Security", Security Dialogue 40 (2009), 399-418; S. Elden, 'Secure the volume: Vertical geopolitics and the depth of power', Political Geography 34 (2013), 35-51. 
to (in)security. This can take several expressions. Some expressions are wellknown, others have hardly been the object of any research at all. Among the former is that the exchange of cultural objects, either voluntary or forced, have often been part of peace negotiations and other political processes aiming at improving the relations between states. The material stuff of heritage, then, has for a long time been viewed by state parties as objects with other values than the monetary that can be bartered with to reach greater objectives. The rebuilding or re-designation of heritage sites, including the selection of sites to direct resources to, is such an action. After the end of the Cold War, reconstruction of heritage was increasingly connected to goals of peacebuilding, increased tolerance and reconciliation between former enemies. This idea was put into practice in Bosnia after 1995, its most visible results being the town of Mostar with its today almost mythical bridge that was inscribed on the World Heritage List in 2004.

Security studies are increasingly asking the questions for whom security is meant, and who has the means to define and make use of security:

... it is not immediately obvious to whom or to what we are referring when we think about, discuss, or seek to achieve security. Should we, for example, focus our efforts on understanding and improving the provision of security for people (as people) or for the states in which those people reside (and are these mutually exclusive) ? ${ }^{9}$

Increased security does not necessarily make everyone feel safer. It also has downsides in that it may create a control society with increased mass surveillance, repressive laws and undermined citizens' rights. For instance, the reconstruction of a mosque that was destroyed in war can potentially make it easier for Muslim refugees to return to this place, or make those already living there feel safer. It could also mean that non-Muslims living in that place feel less secure and see the reconstruction as a threat to their identity and way of living. Heritage resources have to some extent be viewed as useful for the resolution of conflicts and peacebuilding. ${ }^{10}$

\section{Heritage in security}

The struggle for national sovereignty and cultural domination of neighbouring states has a long history in Europe. What security is, and what it means, "cannot be separated from the historical and political contexts in which security is being discussed". ${ }^{11}$ For the purpose of this paper, it is, therefore, necessary to give an overview of how heritage has been securitized and safeguarded in conflicts. The

9 L. Jarvis \& J. Holland, Security. A Critical Introduction (Basingstoke: MacMillan, 2015), 3.

${ }^{10}$ T. Winter, 'Heritage diplomacy', International Journal of Heritage Studies 21 (2015), 997-1015.

${ }^{11}$ Jarvis \& Holland, 21. 
perspective of previous research within this category has been state-centred and has thus identified the needs of people with the needs of nation-states.

Not mentioning the development of wars before the eighteenth century, at the time of the Napoleonic Wars ideas of a common human heritage and cultural property had developed. ${ }^{12}$ That did not mean that heritage or cultural property was left out of the war. The French victories in Europe during the Napoleonic wars made it possible for the French to loot and collect enormous amounts of artworks in Paris and other major towns. Defeated countries had to sign peace agreements in which they agreed that certain collections would be transferred to Paris. The treaty of Tolentino 1797 between France and the Papal States meant that the Vatican lost a large number of artworks that were chosen and picked by the French side under demeaning circumstances. The fall of the French empire and the Vienna congress had as a consequence that a lot of works of art taken from different parts of Europe were to be returned as part of the peace.

International congresses on the protection of heritage developed in the last third of the nineteenth century and may be seen as early efforts to promote ideas of peace and cross-cultural understanding by way of preserving heritage. But, as Astrid Swenson puts it, under "the sweet tones of international unity, the congresses were, like the exhibitions, a battlefield for competing heritage-makers on the national and local level." ${ }^{13}$ Gradually increased tension between France and Germany led to a worsened climate for cross-border cooperation in the years preceding World War I. The reaction against the destruction at Louvain and Rheims during World War I shows how ingrained the beliefs had become that destroying or looting works of art was against international agreements. ${ }^{14}$ In the midst of war, monuments became a symbolic capital that could readily be used for purposes of continuing the conflict with other means than weapons. In mid-war France organised an exhibition in Paris displaying damaged artworks from churches, with the intention of discrediting the Germans and boosting a will to defend the native country against its natural enemies. ${ }^{15}$

In the longer run destroying another country's monuments seemed to adventure international security in post-WWI Europe. The revenge that France

${ }^{12}$ Miles.

13 A. Swenson, The Rise of Heritage: Preserving the Past in France, Germany and England, 1789-1914 (Cambridge: Cambridge University Press, 2013), 198.

${ }^{14}$ Swenson, 227; A. Kramer, Dynamic of Destruction: Culture and Mass Killing in the First World War (Oxford: Oxford University Press, 2009); N. Lambourne, War Damage in Western Europe: The Destruction of Historic Monuments During the Second World War (Edinburgh: Edinburgh University Press, 2001), 13.

${ }^{15}$ C. Kott, ’Kultur' / 'Zivilisation”, in J. Tollebeek \& E. van Assche (eds.), Ravaged: Art and Culture in Times of Conflict (Mercatorfonds: Leuven, 2014), 96. 
and Belgium took in Germany in the Versailles peace included a list of works of art in German collections that should be "returned" to their countries of origin. ${ }^{16}$ In World War II, works of art were well integrated into the Nazi occupation and warfare. At the end of World War II, the collecting and return of stolen artworks were organised by the Allied forces. This was a difficult and demanding task considered a moral obligation to the victims of the war, and a necessary action in order to reverse some of the negative consequences of looting. This was quite a different way of handling the return of cultural property than had been the case in the Versailles treaty, in which the property of only nations, not including individuals, had changed hands. The return of stolen art to private owners can be seen as a way of creating security by restoring the rights of families who had lost heirlooms, valuable property and maybe even having been sent to concentration camps or extermination camps. In the Soviet controlled areas, however, quite a different policy was implemented, which made the looting of German property legitimate.

The opposite, that is how cultural objects may be returned as gestures of peace and improved international relations can also be demonstrated. Even during the chilliest years of the Cold War cultural objects passed the border between East and West in attempts to promote peaceful relations. In 1974 the Swedish prime minister Olof Palme, much to the regret of Swedish heritage officials and political opponents, presented a monumental textile artwork commonly called "the Polish scroll" to his Polish counterpart during an official visit. The scroll had been taken as booty by the Swedish army after its storming of Warsaw in $1655 .{ }^{17}$

The post-cold War era strengthened the concept of security beyond questions of state survival. The 1994 United Nations Human Development Report addressed human misery in its different shapes as security issues, focusing their impact on individuals and communities. ${ }^{18}$ The concept of humanitarian interventions, that is military interventions to protect human rights of people living in an oppressive or failing state, was developed, introduced in practice and criticised in the 1990s. ${ }^{19}$ In the 78-day war of 1999, Kosovo was bombed by NATO to combat Serb aggression against the population. The burning and

\footnotetext{
${ }^{16}$ Nicholas, 123.

${ }^{17}$ O. Bring, 'Moralen väger tyngre än juridiken', Svenska Dagbladet 30 November 2007.

${ }^{18}$ Jarvis \& Holland, 40.

${ }^{19}$ B. Buzan \& L. Hansen, The Evolution of International Security Studies (Cambridge: Cambridge University Press, 2009), 219.
} 
cleansing of villages, including the destruction of ethnically defined heritage, formed part of the argument supporting a humanitarian intervention. ${ }^{20}$

The Yugoslavian wars of 1991-95 introduced the term "cultural cleansing", meaning the deliberate destruction of cultural property with the intention of damaging the identity and memory of an ethnic group. Heritage came to play a role in the international community's perception of the conflict both during the war and afterwards. The attacks on the historic towns of Dubrovnik (1991) and Mostar (1993) not only caused immediate international outcry but also shaped post-conflict reconstruction in the Balkans for many years. The rebuilding of Mostar became a symbol for the international will to compensate $\mathrm{BiH}$ for the war and to promote peace by way of reconstructing an urban landscape. As Helen Walasek has pointed out, the actors involved may have made some critical mistakes by not by trying to create a common heritage but rather singling out the three distinctive ethnic identities of Bosniaks, Croats, and Serbs, and then promote each one of these. ${ }^{21}$ In this way many of the negative effects of the war might have been reinforced, using heritage to give legitimacy to ethnic enclaves.

Another political heritage process initiated after the war has been the more or less forced return of cultural objects from Serbia to $\mathrm{BiH}$ and Croatia. In order to normalise relations between the countries, it is considered necessary to repatriate collections to churches and museums from which they were removed before or during war-time. Paradoxically, such movements were often carried out with reference to the objects' safekeeping - collections needed to be moved out of the war zone in order to be secure. The repatriation of cultural objects is still today an ongoing administrative process. ${ }^{22}$ But there have also been some attempts to display and tell about the multi-ethnic history of the Balkans, in order to promote reconciliation, tolerance, and non-violence.

The end of the Cold War and the new conflicts of the 1990s led to the creation of the international criminal courts ICC and ICTY. This development can be understood as a strategy for developing an international network of prosecuting international criminals. ICTY was the first court for war crimes introduced since the Nuremberg trials. Two military officers were condemned for charging the assault on Dubrovnik, not only killing civilians but also damaging heritage. ${ }^{23}$ ICTY described their crimes as a targeting of monuments not only of regional relevance but important for all of the humanity since Dubrovnik is

\footnotetext{
${ }^{20}$ Herscher, 75.

${ }^{21} \mathrm{H}$. Walasek, Bosnia and the Destruction of Cultural Heritage (London: Routledge, 2015), 225.

${ }^{22}$ See for example http://www.balkaninsight.com/en/article/croatia-urges-serbia-to-returnreligious-artefacts-01-04-2017.

${ }^{23}$ Legnér, 'Attacker ..., 145.
} 
a world cultural heritage protected by UNESCO. ${ }^{24}$ In 2016 ICC convicted for the first time a person accused of destroying the heritage of importance for all humanity. At about the same time political leaders in Europe cried out against the destruction conducted by ISIS in Syria and Iraq against heritage that is of value to all humanity. Looting and trading with antiquities from Syria and Iraq in Western countries are believed to significantly contribute to the funding of the war, thus contributing to a continued humanitarian crisis in the region, with consequences for the whole of Europe.

It is becoming clearer that international heritage politics exercised by UNESCO, ICOMOS, the World Bank and others become actors in interstate as well as intrastate conflicts. In 2003 UNESCO proclaimed the destroyed Bamiyan sculptures of Aghanistan a world heritage site, designated to remind the world of the destructiveness of the Taliban movement. A world heritage site was inscribed chiefly to commemorate a conflict. UNESCO keeps a list of endangered world cultural heritage sites, implying that certain heritage runs the risk of becoming extinct or severely damaged due to different kinds of conflicts or other 'deficits' of security. The year before was the UN year of cultural heritage, in which it was emphasised how "cultural heritage is an instrument for peace and reconciliation". ${ }^{25}$ This also means that UNESCO believes that different actions can be taken to alter the risk of future extinction and improve the status of these sites. A consequence of this rhetorical reference to the need for heritage protection is that cultural property is increasingly woven into a global discourse on whose heritage is represented and by whom. ${ }^{26}$

\section{Heritage as security}

Heritage as security is identified as a category of research largely missing, although there is an abundance of reports, accounts and personal experiences witnessing of its relevance. If the first category has centred on the state as a central actor in providing security to its citizens and national heritage, the second category will focus individuals, sub-state level groups and organisations working across borders. The underlying argument is that states, and perhaps even more so states in conflict, are heterogeneous and unstable. Human security studies acknowledge that the "process of identifying the person, collectivity or thing that is having its security threatened is itself a deeply political act, with important

\footnotetext{
${ }^{24}$ Walasek, 313.

${ }^{25}$ Quoted in T. Kälvemark, Cultural Heritage for Peace and Reconciliation. An evaluation of Cultural Heritage without Borders (Stockholm: Cultural Heritage without Borders, 2008), 5.

${ }^{26}$ M. Legnér, 'Kulturarvsbruk i väpnade konflikter', Historisk tidskrift 136 (2016), 669.
} 
political consequences" ${ }^{27}$ It is not evident who is providing security for whom. Many heritage interventions in the Balkans have been shaped by views on which group was victimised in the conflict, and which one was the perpetrator. ${ }^{28}$

The Yugoslavian wars of the 1990s had profound consequences for identities, collective memory and heritage in the Balkans, but its consequences were not limited to this region. Sweden, among many other countries, was also affected in a number of ways. The country received c. 100,000 refugees, mostly from Bosnia, during the war, and somewhat later during the Kosovo crisis, a few thousand Kosovo Albanian refugees were offered a haven in Sweden. Continual news reporting about the atrocities of the war in Bosnia gave the Swedish government reason to organise emergency aid to the region after the Dayton peace agreement had been signed. This aid would come to be re-organised several times and given continuously for many years to come. One organisation that quickly became an integral part of Swedish aid to Balkan was the non-governmental foundation Cultural Heritage without Borders (CHwB), founded in Stockholm 1994 as a direct consequence of the war in Bosnia, and with the mission to restore and preserve cultural heritage in areas of conflict or natural disaster.

Questions raised in this case are: What assumptions, beliefs, and values underlie the language in texts created by $\mathrm{CHwB}$ and SIDA (Swedish International Development Agency) about the importance of working with heritage after the Balkan conflicts? Is there any belief, expressed in documents or in conversations, that heritage can be used to provide security and safety? If so, in what ways?

SIDA's mission is to contribute to the development of the economy, governance and civil society of poor countries. Needless to say, cultural heritage has had a very small piece in the overall aims of the organisation. Following the Yugoslavian wars, however, there seems to have been an increased sense of the importance of supporting the construction of identities, memories, and traditions in places where these had been deliberately recast in violent ways. In 2005, shortly after both Mostar and Bamiyan had become world heritage sites, SIDA published its first policy paper on cultural heritage. In this paper the agency's view on destructive acts against heritage, and the possibilities of using heritage to promote peace after a conflict is developed:

Peace is a given pre-requisite for sustainable development. However, peace will be undermined if the rights of minorities are diminished if fuel is added to ethnic discord and if religious and cultural intolerance is accepted. During the latest armed conflicts, the cultural heritages of opposing groups have

${ }^{27}$ Jarvis \& Holland, 95.

${ }^{28}$ This is discussed in an upcoming article: M. Legnér, 'Post-conflict reconstruction and the heritage process', Journal of Architectural Conservation, in print (2018). 
been used as targets. On the one hand, cultural heritage can be used to strengthen a group's own identity, which may have a benign and inspirational effect, especially in the case of newly founded states. On the other hand, it can be used as part of a ruling strategy that tries to cement the legitimacy of the "superior" groups and therefore excludes other interests. In the last few decades, religious groups have destroyed each other's holy shrines to an ever-increasing extent. Monuments are used as territorial markers, whilst archaeology and history are abused to further the claims of one's own national group to primacy. ${ }^{29}$

This quote, then, touches not only on the obviously negative effects of physical violence carried out but also mentions the problem of structural violence and how history and heritage can be used to strengthen one group in a state at the expense of others. A broad support of heritage was considered necessary in the continued strives of SIDA to support the emergence of multiethnic and multicultural society in the Balkans.

$\mathrm{CHwB}$ was quick to catch this increased interest from SIDA. Its aims have been described in numerous folders and booklets published by the NGO. In one of the more recent ones $\mathrm{CHwB}$ describes its mission:

Reconciliation efforts are urgently needed as ways of mitigating against further hostilities and of preparing for a life where peoples and communities can live and work side by side again. There is considerable evidence that working with reconstruction, conservation and the development of historic environments can help promote peace-building processes, strengthen selfesteem, and contribute towards socio-economic development. ${ }^{30}$

This text has a high level of abstraction in that it stresses the generally positive effects of working with heritage in areas where there has been armed conflict. It expresses a strong belief in the possibility of "normalising" peoples' lives in such areas, and that this can be achieved at least partly by working with historic environments. Cultural heritage is described almost as a panacea for the ills of war, and those who work with it are in that ways understood as doctors curing a sick patient. Interestingly, the statement that there is "considerable evidence" is not followed by any references to any such successes. The reader is supposed to believe the message and trust the authors that it is a correct description of the role of heritage in peacebuilding.

How have such abstract and, somewhat bluntly put, superficial texts been understood by the field workers of $\mathrm{CHwB}$ themselves? How do they look at their own work? Is it in some way associated with issues of security, safety,

${ }^{29}$ Caring for the historic environment (Stockholm: SIDA, 2005), 11, compare 14.

${ }^{30}$ Bridges to the future (Stockholm: Cultural Heritage without Borders, 2015), 5. 
conflict resolution, and prevention? There should be a dialectic between beliefs in the positive effects of working with heritage in conflict areas, and personal experiences and memories from such work. This dialectic can be understood better by interviewing people who have been involved in $\mathrm{CHwB}$. In order to grasp the extent to which the discourse on reconciliation and peace is grounded in individual experiences and beliefs, it has been vital to carry out interviews.

Several persons involved in $\mathrm{CHwB}$ work who were interviewed seem to be convinced that damaged heritage buildings that are not restored will become a symbol of past crimes and will make reconciliation more difficult. ${ }^{31}$ The best way to work is to restore these buildings and let them "regain their value". With that reconciliation will follow. The impression is that this is quite an instrumental process that follows a number of steps and leads to good results, building on the values of heritage. The idea is that the politics of conflict can be separated from the inherently good values that are carried by the materialities left from the past. As one interviewee put it: "We don't have a political agenda. Our agenda is the cultural heritage." 32 Heritage in itself is thus not seen as political.

Some messages are recognised from $\mathrm{CHwB}$ pamphlets. It is believed that at least some of the antagonism between the ethnic groups can disappear as a result of working with tangible heritage. The argument, then, is that in the same way as heritage sites can become targets with the aim of causing harm to the identity and collective memory of a group, the restoration of these buildings can to some extent reverse that process. One long-time board member of $\mathrm{CHwB}$ was however not convinced of the power of heritage to heal mental wounds, but argued that "at least it could be perceived in that way by some" 33 , meaning that $\mathrm{s} /$ he did not believe this him/herself but thought that others did, and perhaps especially the funding bodies.

Reconciliation cannot be taken for granted, however. Success is in general dependant on how projects are designed and implemented. A former chair of $\mathrm{CHwB}$ mentions, among other examples, the failed attempt to initiate a project on Kosovo Polje, the site of the mythical battle of Kosovo AD 1389. This battle has a special place in Serb collective memory and especially among nationalists who continue to argue that Kosovo is a legitimate part of Serbia. The aim of the proposal was to use the battlefield to work with both the Kosovo Albanian population and the Serbian population. A museum of the battlefield, partly

${ }^{31}$ Interviews with: former $\mathrm{CHwB}$ chair in Stockholm 20 August 2016; board member in Stockholm (via Skype) 26 February and 9 March 2016; CHwB chair in Uppsala 25 October 2016.

${ }^{32}$ Interview with former CHwB chair in Stockholm 20 August 2016.

${ }^{33}$ Interview with CHwB board member in Stockholm 18 August 2016. 
destroyed, would be restored together with a Muslim cemetary nearby. "No one was interested in funding the project", probably because of the extremely strong associations that are made between the field and the historical belief that this battle was constitutive for the creation of the Serbian nation. ${ }^{34}$ In this instance, the idea to work towards reconciliation and understanding between the two ethnic groups was not possible to carry out.

An interview was conducted with a co-worker who has worked for $\mathrm{CHwB}$ Kosovo for a long time. ${ }^{35} \mathrm{~S} /$ he argues that it - much like in Bosnia Herzegovina - is not possible to speak of a common Kosovar cultural heritage. It is still divided between a Serbian and a Kosovo Albanian part. For $\mathrm{CHwB}$ it has not been possible to base projects in the northern, Serb-dominated part of the territory. The situation in northern Kosovo is described as a "frozen conflict" since Serbia threatens with actions as soon as one or the other political issue becomes current. There have been problems but also success in cooperation with Serb communities in the western part of Kosovo. Foremost among the successes is the work with seven municipalities, of which one is dominated by Serbs, in establishing management plans for their cultural heritage.

One formative moment in $\mathrm{CHwB}$ interventions in Kosovo was the March 2004 riots, in which Serbian orthodox churches and monasteries were stormed and vandalised as "an act of Kosovo Albanian retaliation" against the Serb population. ${ }^{36}$ The buildings of the church are the most prominent and visible symbol of Serb presence in Kosovo and have, therefore, become an attractive target for violent Albanian chauvinists. Another $\mathrm{CHwB}$ co-worker, also based in Kosovo, presents the conspiratorial theory that the March riots were actually organised by Serbs and not by Kosovo Albanians. ${ }^{37}$ This theory lacks support in historical accounts of the 2004 unrest. $^{38}$

Churches and monasteries became much more important in Kosovo after the war of 1998-99 than they had ever been before for the Serbs. Some of the monasteries were added to the UNESCO world heritage list shortly after the riots. ${ }^{39}$ One aim was obviously to secure the position of Serbian heritage in the UN administered territory of Kosovo. Most of the Serbs had already left the country, so the government in Belgrad needed the Serbian orthodox

\footnotetext{
${ }^{34}$ T. Judah, The Serbs. History, myth and the destruction of Yugoslavia (New Haven: Yale University Press, 2009), 3rd ed., Chapter 3.

${ }^{35}$ Interview with $\mathrm{CHwB}$ co-worker in Kosovo 19 April 2016.

${ }^{36}$ The riots and their consequences are described in Herscher, 141-148.

${ }^{37}$ Interview with $\mathrm{CHwB}$ co-worker, Kosovo, 1 November 2016, followed by clarification in email to the author 15 November 2016.

${ }^{38}$ For one account of the riots see Herscher, 141-148.

${ }^{39}$ See UNESCO nomination: http://whc.unesco.org/en/list/724
} 
church in order to support its continued demands on Kosovo. She/he was on the way to Stockholm to participate in a multiethnic conference organised by $\mathrm{CHwB}$, but the meeting had to be interrupted because of the incident. Serb, Kosovar and Bosniak participants could suddenly not talk to each other. The Swedish hosts of the meeting did not entirely understand what had

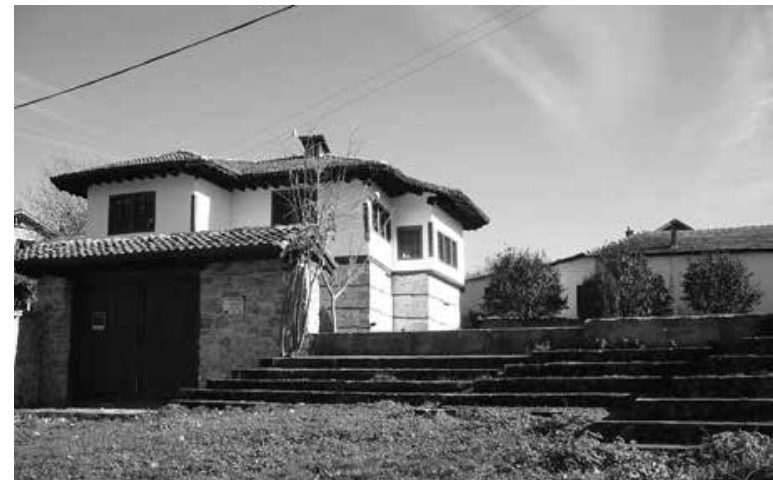

Image 1. The community centre in Velika Hoča that was restored in cooperation between Serbs and Kosovo Albanians, and under the management of CHwB (2002). Photo by the author (2016). just happened in Kosovo or why, and were accused of not acting as a neutral part.

A project that is considered successful by SIDA is mentioned in which the two ethnic groups actually worked together (Velika Hoča). A Serb enclave in western Kosovo was looking for help to restore a seraj into a community centre. The church tried to control the project and would not allow Kosovo Albanians into the village. Another problem, according to the former chair, was that the church would not allow women into the church. $\mathrm{CHwB}$ would at least not in this project cooperate with an organisation that supported a patriarchal vision of society. Despite this initial conflict Kosovo Albanians from $\mathrm{CHwB}$ managed to work together with male villagers without the involvement of the church. It is, of course, dubious to which extent this work encouraged permanent reconciliation. The project was limited in time and was dependent on SIDA funding. Villagers working in the project received a salary while cooperating. The Velika Hoča project is however also mentioned as exemplary by persons outside of $\mathrm{CHwB}$. In an interview, a SIDA official working at the Swedish embassy in Kosovo brings the project up as a big success when it comes to using heritage for peacepromoting purposes. ${ }^{40}$ However, the official does not seem to have visited the village for a long time, since $\mathrm{s} /$ he is not able to comment recent development there.

After the SIDA-funded project in Velika Hoča, there was a second restoration project carried out in 2014-15 funded by the United States Ambassador's Fund. The object was an old winery building that had decayed due to lack of care, which was to be restored. The aim is described on the $\mathrm{CHwB}$ website:

${ }^{40}$ Interview with SIDA official in Pristina, 4 November 2016. 
The aim of this project is to preserve the cultural heritage values of the village. Thus, to revitalize economic activities through preservation of traditional trades - viniculture, natural and cultural heritage tourism. Furthermore, to promote the full and active participation of non-majority communities as stakeholders in society and finally, to contribute to the post war reconciliation process by using heritage as a tool (for) dialogue. ${ }^{41}$

During a visit to the village in October 2016, fourteen years after the project, there was no activity in the buildings that had been restored with SIDA funding. They were locked and apparently not in use. There is wine production going on in the village, organised by the church and with most of the wine exported to Serbia, but the restored winery does not seem to have a function

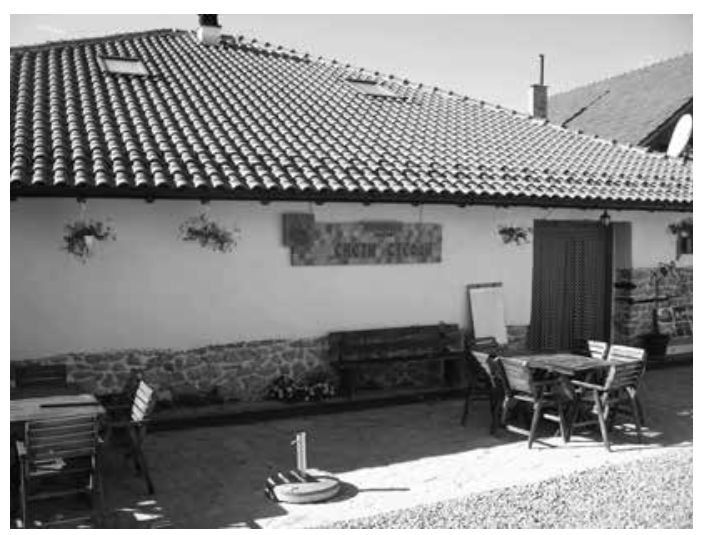

Image 2. Saint Stefan wineyard building in Velika Hoča, restored by CHwB (2014-15). Photo by the author (2016). within the production. The two projects of the village raise a number of issues with using restoration projects for purposes of economic regeneration, community involvement, and reconciliation. Taken that the above mentioned aim is seriously meant, how does the discourse on community regeneration by use of restoration become relevant to people living in the community? And how could acts of reconciliation possibly be expressed within the frame of a restoration project? It remains unclear whether the restoration itself is supposed to be viewed as an act of reconciliation, or if reconciliation rather is an effect that will follow on the restoration of buildings.

The argument that reconciliation would be possible to reach by restoring buildings is criticised by a former $\mathrm{CHwB}$ co-worker. She is an architect who bases her experiences on restoration work carried out in Bosnia Herzegovina, and who has published an account of her experiences in the early 2000s. ${ }^{42}$ An interview with her has also been conducted. ${ }^{43}$ She argues that a feeling of increased safety for the local population is a strong enough motive for organisations to become

\footnotetext{
${ }^{41}$ Quote from project description (author's italic): http://chwb.org/kosovo/activities/an-activity/

${ }^{42}$ Wik in Walasek.

${ }^{43}$ Interview with Tina Wik in Stockholm 19 August 2016.
} 
involved in the rebuilding of heritage. It is, however, naïve to expect that such work would result in reconciliation between ethnic groups.

Who would feel safer through the restoration of buildings that are clearly identified with one or the other ethnicity, is a question she does not explicitly put but is an underlying basis of her argument. If interventions are concentrated on the heritage that is not viewed as common for a community but is rather identified as belonging to one party in a conflict, then it may mean that other groups feel less safe and secure than before. Wik witnessed how restoration, aimed to promote tolerance and respect for the Other, paradoxically could give new life to conflicts. Communities whose ethnic composition had changed due to the war in Bosnia could suddenly oppose the rebuilding of destroyed mosques or other heritage identified as Muslim. In some places, mosques were rebuilt as museums when there was no Muslim congregation left. The motive was then to try to counter the purpose of cultural cleansing by showing that the place had a multi-ethnic history and that Muslims had been living there not long ago.

This was an active way for foreign organisations to influence heritage processes in Bosnia. The construction of a previously destroyed mosque was clearly a symbolic act meant to show that previous crimes were not forgotten, that Muslims had a right to exist and practice their religion in the community, and that it was safe for them to return. The restoration of mosques, cemeteries, bazaars and other historic sites associated with the Ottoman age were used to ground a feeling of security for a population that did not actually live in that place any longer, but could potentially return in the future. Alternatively, restoration was used to make Muslims already living there feel safer by recreating pieces of an imagined past.

At least in a few instances, such intentions of restoration work in Bosnia in the early 2000s were violently opposed, showing that the act of restoration could result in violence and less safety on the actual site. Such an incident was the anarchy that broke out in Banja Luka on 7 May 2001, which was the anniversary of the destruction of the Ferhadija mosque. The mosque had been blown up and completely razed by Bosnian Serb forces on the night between 7 and 8 May 1993. On 7 May 2001, a ceremony was held in which a cornerstone of the mosque was to be laid in order to mark the beginning of the reconstruction. The ceremony, hosted by diplomats and other foreign dignitaries, was interrupted by a large mob of Bosnian Serbs who wreaked havoc on the site. ${ }^{44}$ In the years to come the rebuilding of Ferhadija remained an issue of conflict in the city, and first in 2005 could preparatory work take its beginning. ${ }^{45}$ This instance shows

\footnotetext{
${ }^{44}$ Wik is interviewed about the incident in the Swedish paper Expressen 8 May 2001.

${ }^{45}$ Walasek, 220-222.
} 
how restoration and reconstruction of heritage can be connected to notions of security as well as insecurity. For an international community, Ferhadija was interpreted as a step towards increased safety for Banja Luka Muslims, but in believing this the foreign powers grossly underestimated the resistance by local Serbs, of whom at least some saw the act of rebuilding as a threat against their (new) way of life.

There are numerous ways in which uses of heritage for peacebuilding purposes connects to visions of (in)security. $\mathrm{CHwB}$ has not only worked with the restoration of monuments but also with museums in the Balkans. One $\mathrm{CHwB}$ board member, working as a curator, tells stories of how s/he together with colleagues have tried to make museum staff from Bosnia Herzegovina, Kosovo and Serbia work together within the Balkan Museum Network that was created by the NGO. ${ }^{46}$ It seems as if security issues have played a somewhat lesser role in this cooperation between professionals. In such a relation it has been possible, at least at times, to identify common goals to work towards. But museum management in the region is highly involved in national politics. Managers can quickly be replaced if a new government, or even just one minister, gets into power. Within the Balkan Museum Network s/he invited museum staff from the different countries to Sweden in 2006. Initially, the organisers were concerned of how the meeting would play out since this was the first time that staff from the different countries met after the wars. The meeting proved to be a success in that it was possible to cooperate when staff members met on neutral ground rather than in one of the countries of origin. Her/his general experience is that it often, but far from always, is possible to use heritage for purposes of reconciliation and peacebuilding.

Another curator and former $\mathrm{CHwB}$ board member partially agrees with this view. ${ }^{47} \mathrm{~S} /$ he also speaks of the high degree of politization of the management of Balkan museums. One example was the Kosovo museum in Pristina, which went against ideas of reconciliation and instead produced an exhibition on the Kosovo war, in which guns and bloodied uniforms were displayed. In such a chauvinist exhibiton "they (the Kosovo Albanians) wished to demonstrate the bloodthirst of the Serbs", and that was counter-productive. S/he also has experience from working the Musei Semaljski in Sarajevo and points out the problems with managing a national museum in Bosnia Herzegovina. It was governed by the interests of the different parties: Bosniaks, Serbs, Croatian Catholics. The Serb party wished to move cultural objects from the collection to its capital Banja Luka, and the Croatian party wanted objects to be transferred to Mostar. As long

\footnotetext{
${ }^{46}$ Interview with $\mathrm{CHwB}$ chair, Uppsala 25 October 2016.

${ }^{47}$ Interview with CHwB board member, Stockholm 23 November 2016.
} 
as objects were kept in a city that was not dominated by an ethnic group to which the heritage was identified as belonging to, they were not considered to be safe by those who claimed them. There was a constant problem in cooperating with the aim of presenting a national history and to promote efforts of reconciliation. $\mathrm{S} /$ he also gives another insightful comment when acknowledging that as an outsider (a Swede working temporarily in the country) it was difficult always to understand the concerns of museum staff, who did not want to visit other parts of $\mathrm{BiH}$. It was, for example, difficult to make professionals working in Banja Luka visit Sarajevo, most probably because they were worried for their own safety.

\section{Concluding discussion}

The case study has been occupied with identifying how issues of security and safety may become relevant in heritage politics following the Yugoslavian wars. Whereas heritage in security can be understood as the implementation of security policies and practices on cultural heritage in conflicts with states as primary agents, the category of heritage as security is presented as an alternative approach to studying the interconnectedness between heritage and security. The case was used to show how heritage interventions can be seen as either providing security in a community or constituting a threat to its survival.

Restoring buildings or conserving museum collections can be seen as efforts to secure remains of the past for future generations, or as aims to achieve increased security for people by carrying out symbolic acts of restoration in which important markers of their culture are tended to and re-established after having been targeted in a conflict. In the first instance, it is regarded as important to identify, select and conserve values of remains from the past that will bear proof to the presence and former life of a group at a specific site. It could be seen as an effort not only to secure but also actively construct a collective memory that could otherwise risk being forgotten. In the second instance, there is an aim of making a victimised group more visible and to grant it recognition.

Organisations managing heritage interventions most often seem to be much more adept at identifying cultural objects to be rescued, rather than identifying groups or individuals who are supposed to appreciate and value the object once the intervention has finished. It often seems as if the recipient community of a restoration is vaguely identified either as a diaspora of people who have left the place, and who might return if they consider it safe again, or people who are living there and whose lives may become richer by having a historically important resource brought back. Security is then broadly understood as those factors that make it possible to subsist, and includes the possibility of earning a living, to provide schools for the children, to practice religious beliefs, and 
to know that you can move about freely without being harassed or becoming a victim of violent crime. The conditions for reaching such a level of safety can, of course, differ greatly not only between religious or ethnic identities but also between men, women, and children, and also between social strata in society. It is not given that safety for men is the same as safety is for women, for example. ${ }^{48}$

There is also the paradox that aims of creating more security for one population could be perceived as a step (and consequently also as a threat) towards greater insecurity by another population: if one wants to live in a monoculture, the international recognition of a suppressed ethnicity may be understood as a rejection of one's way of life. There may also be other problems with the aim of creating security through the restoration of heritage. By restoring mosques or orthodox churches, are nongovernmental organisations helping only a small fraction of a population? Are women and girls helped by the fact that large economic resources are being spent on the reconstruction of the property of patriarchal institutions, which are strongly gendered and oppose equality between the sexes?

"(I)dentities, interests, and threats exist and interact as social productions, rather than as pre-given entities", say Jarvis and Holland. ${ }^{49}$ Such a view makes it fruitful to understand heritage interventions as dynamic relationships between actors, their identities, and beliefs about security and threats. Interventions may affect identities and cause a number of responses: ceremonies, celebrations, and appreciation, but also violence and fear, depending on the historical and political contexts in which interventions are carried out. Heritage has often been used as if it represents a static and well-defined identity that more or less automatically should exclude other identities. This is a problematic but common view within organisations funding or performing interventions. Studies on the relation between heritage and security could serve to analyse and break down that kind of counter-productive work and suggest alternative ways of working.

\section{Rezumat}

Există legături intre politicile de securitate, consolidarea păcii şi politicile de patrimoniu? Scopul acestei lucrări este de a discuta despre modul în care politicile patrimoniului cultural sunt utilizate pentru a elabora și a consolida politicile și practicile de securitate, care, în mare parte, rămân necunoscute. În al doilea rând, este, de asemenea important să încercăm să înțelegem mai bine modul în care politicile de securitate pot fi influențate de noțiunile de moștenire culturală și de anumite intervenții asupra siturilor de patrimoniu.

\footnotetext{
${ }^{48}$ Buzan \& Hansen, 208-212.

${ }^{49}$ Jarvis \& Holland, 225.
} 
Autorul argumentează faptul, că a devenit necesar să trecem dincolo de studiul războaielor, pentru a înțelege mai bine modul în care patrimoniul cultural afectează securitatea și viceversa, nu numai în timpul conflictelor, dar și în perioade de pace, și, mai ales, în perioada „după război”. Lucrarea se bazează pe o analiză critică a cercetărilor anterioare, în special asupra studiilor privind patrimoniul cultural și, parțial, asupra studiilor de securitate. Studiul de caz dezbate modul în care aspectele legate de securitate și siguranță pot deveni relevante în politica patrimoniului cultural din Balcani. Studiul servește pentru a demonstra modul în care intervențiile patrimoniului pot fi văzute ca furnizor de securitate într-o comunitate, fie ca o amenințare pentru supraviețuirea ei.

Cuvinte-cheie: Securizare, patrimoniu cultural, reconciliere, reconstrucție post-război, insecuritatea balcanică, conservare, Urbicide. 